\title{
Analysis of peonies cultivars and their parental forms using RAPD primers
}

\author{
Judita Varkulevičiene $\dot{~}^{1^{*}}$, \\ Judita Žukauskienè ${ }^{2}$ \\ ${ }^{1}$ Kaunas Botanical Garden of \\ Vytautas Magnus University, \\ Ž. E. Žilibero St. 6, LT-46324 Kaunas, \\ Lithuania \\ ${ }^{2}$ Faculty of Natural Sciences of \\ Vytautas Magnus University, \\ Vileikos St. 8, LT-44404 Kaunas, \\ Lithuania
}

\begin{abstract}
It is very important to select genetically and morphologically different individuals creating new, physiologically different peony cultivars. Genetic differences of morphologically similar species cannot be assessed only by comparing the external features. Investigated peonies varied morphologically by the height, type of blossom, shape and color, aromatic features, strength and number of stems, leaf density and color, flowering time and duration. Genetic differences between 13 different peony cultivars, which are growing in the Kaunas Botanical Garden of Vytautas Magnus University, were compared using a random amplified polymorphic DNA (RAPD) method. 9 RAPD primers were chosen for a genetic analysis. The number of DNA fragments varied from 1 to 15 , and their length from 100 to 1800 base pairs (bp). Most of polymorphic DNA fragments were amplified with four chosen primers: MP-8, OPB-7, OPA-18 and OPB-8. A total number of different-sized DNA fragments ranged from 1 to 15 , and their length ranged from 100 to $1800 \mathrm{bp}$. The genetically most distant peony cultivars were 'Skeivienès vèlyvasis' and 'Garbè Motinai'. The genetically closest peony cultivars were 'General Mac Mahon' and 'Germaine Burgos'. The genetically closest cultivar to its parental forms was 'Freda', and the most distant cultivars were 'Darius-Girènas' and 'Skeivienès vèlyvasis'.
\end{abstract}

Key words: Paeonia lactiflora, cultivar, Lithuanian, RAPD

\section{INTRODUCTION}

The gene pool of plants, animals and other useful living organisms is an important national estate of every country. Numerous plant collections are stored in science and study institutes of Lithuania.

According to plant groups, storage and research of national plant genetic diversity is coordinated in these science and study institutes:

\footnotetext{
* Corresponding author. E-mail: j.varkuleviciene@bs.vdu.lt
}

Lithuanian Institute of Agriculture, Lithuanian Forest Research Institute, Lithuanian Institute of Horticulture and Floriculture, Vilnius University Botanical Garden and the Ornamental Plants Sector of Vytautas Magnus University Kaunas Botanical Garden (Varkulevičienè et al., 2006; Dapkūnienè et al., 2007). Peonies were cultivated firstly in China and Japan because warm full winter over there is perfect for growth of herbaceous and tree peonies. Intensive genetic researches of peonies have been carried out in China and Japan since 1996 (Cheng et al., 2011). 
The first molecular researches of tree peonies were carried out using the RAPD method. This method was successfully used for identifying genetic kin as well as for new cultivar identification. Most of the studies focused on the establishment of phylogenetic relationships among wild species or interspecies. A few molecular marker techniques have been applied to analyze tree peony cultivars such as RAPD (Chen et al., 2001; SU et al., 2006), AFLP (Liu et al., 2006) and ISSR (Suo et al., 2004; Suo et al., 2005). Big attention is focused on biochemical researches of peonies (Bomi et al., 2008).

A DNA polymorphism analysis was made on herbaceous peonies species and cultivars in the Lithuanian Institute of Horticulture and Floriculture (LIH) (Mažeikiené et al., 2007). Peonies are widely used in selection because their genes change slowly and/or do not change for many years (Halevy et al., 2002). Comparison of peonies external characteristics lack capabilities of evaluating how peony species or cultivars are genetically different (Mažeikienè et al., 2008).

After a morphological trait evaluation 10 peony species and 7 cultivars were rated and genetically evaluated in the ornamental plant collections in LIH (Mažeikienè et al., 2008). Researches were conducted on these peonies: 2 examples of Paeonia lactiflora, 2 seedling forms of $P$. officinalis (alba plena and rose plena), $P$. tenuifolia, $P$. tenuifolia var. plena, $P$. peregrina, $P$. daurica, $P$. anomala, $P$. veitchii and five $P$. lactiflora cultivars and hybrids created by O. Skeivienè - 'Garbè Motinai', 'Virgilijus', 'Prof. K. Grybauskas', 'Maironis', 'DariusGirenas', and 2 worldwide cultivars created by French plant breeders: 'Sarah Bernhard' and 'Festiva Maxima'. Herbaceous peonies in the ornamental plants collection in LIH show a large variety of morphological features. Peony species and cultivars were polymorphic in different ways according to the basis of morphological and genetic characteristics (Mažeikienè et al., 2008). Search of genes and their expression researches allow accessing the peony plant cell genetic response to environ- mental conditions (Mažeikienè et al., 2010). Peony genetic alterations in low temperatures were also studied (Mažeikienè et al., 2010).

Peony introduction and selection were performed by Ona Skeiviene in the Kaunas Botanical Garden of Vytautas Magnus University since 1947. During 1953-1958 a comparable rating of created hybrids was made. There were selected 6 promising hybrids: 'Skeivienès vèlyvasis', 'Virgilijus', 'Darius-Girènas', 'Garbė Motinai', 'Freda', 'Prof. K. Grybauskas' (Skeviene, 1964). Three hybrids - 'Garbe Motinai', 'Prof. K. Grybauskas' and 'Virgilijus' - were created locally in 1976. Copyright was granted to the originator Ona Skeiviene in 1979. Ona Skeiviene is an author of other 16 hybrids, that are candidates for the cultivars. The peonies collection was mentored by Ona Skeivienè till 1976 (Varkulevičienè et al., 2005, 2006; Varkulevičienè et al., 2013). Genetic relatedness of cultivars and hybrids of Lithuania and introduced species and cultivars has not been studied extensively.

This study evaluated the genetic difference of a total of 13 samples including Lithuanian 6 peony cultivars and their parents.

\section{MATERIALS AND METHODS}

DNA extraction from peonies. Thirteen peony cultivars (6 Lithuanian cultivars and 7 parental forms) were chosen from the field collection in the Kaunas Botanical Garden of Vytautas Magnus University (Table 1).

Fresh young leaf material was sampled in spring. DNA extraction was made using a CTAB (Murray and Thompson, 1980) method modified by Areškevičienè (2009).

DNA analysis by RAPD method. Nine primers were used for the RAPD-PCR analysis (Table 2). DNA amplification reaction was performed in the $25 \mu \mathrm{l}$ reaction mix made of $12.5 \mu \mathrm{l} 2 \times$ PCR Master Mix $(0.05 \mathrm{U} / \mu \mathrm{l} \mathrm{Tag}$ DNA polymerase; $4 \mathrm{~mm} \mathrm{MgCl}_{2} ; 0.4 \mathrm{mM}$ each dNTP) (Thermo Scientific, Lithuania), $2 \mu \mathrm{l}$ primer (concentration $10 \mathrm{pmol} / \mu \mathrm{l}$ ) (Roth, Germany), $6.5 \mu$ twice distilled water and $4 \mu \mathrm{l}$ $(25 \mathrm{ng} / \mu \mathrm{l})$ DNA. PCR reaction was performed in a thermo cycler (Master Cycler ${ }^{\oplus}$, Eppendorf, 
Table 1. Pedigrees of the Lithuanian peony cultivars and their parental forms in this study

\begin{tabular}{|c|c|c|c|c|c|c|}
\hline \multirow[b]{2}{*}{ Parental forms } & \multicolumn{6}{|c|}{ Peony cultivars } \\
\hline & 'Virgilijus' & $\begin{array}{c}\text { 'Garbè } \\
\text { Motinai' }\end{array}$ & $\begin{array}{c}\text { 'Prof. K. Gry- } \\
\text { bauskas' }\end{array}$ & 'Freda' & $\begin{array}{l}\text { 'Darius- } \\
\text { Girènas' }\end{array}$ & $\begin{array}{l}\text { 'Skeivienès } \\
\text { vėlyvasis' }\end{array}$ \\
\hline 'Auguste Dessert' & $\mathrm{x}$ & & & $\mathrm{x}$ & & \\
\hline 'Germaine Burgos' & & $\mathrm{x}$ & & & $\mathrm{x}$ & \\
\hline 'General Mac Mahon' & & & $\mathrm{x}$ & & & \\
\hline 'Perette' & & & $\mathrm{x}$ & $\mathrm{x}$ & & \\
\hline Madame Calot' & & & & & $\mathrm{x}$ & \\
\hline 'Eugene Verdier' & & & & & & $\mathrm{x}$ \\
\hline 'Germaine Bigot' & & & & & & $\mathrm{x}$ \\
\hline
\end{tabular}

Germany) under the following conditions: initial denaturation for $3 \mathrm{~min}$ at $94{ }^{\circ} \mathrm{C}, 45$ cycles of denaturation for $45 \mathrm{~s}$ at $94{ }^{\circ} \mathrm{C}$, primers annealing for $45 \mathrm{~s}$ at $32-52^{\circ} \mathrm{C}$ (depending on the primer), extension for $45 \mathrm{~s}$ at $72^{\circ} \mathrm{C}$ followed by a final extension for $5 \mathrm{~min}$ at $72^{\circ} \mathrm{C}$.

The amplified DNA fragments were separated according to their molecular weights using electrophoresis on 1.5\% agarose gel prepared in a 1 XTBE buffer. A standard molecular marker - Gene Rulers ${ }^{\mathrm{TM}}$ DNA Ladder Plus (Thermo Scientific, Lithuania) - was used to determine the molecular weight of the amplified bands. Gels were examined visually under UV light using ethidium bromide. The gels were photographed and documented with a Hero Lab transilluminator and a Win32 system (Hero Lab, Germany).

Statistical analysis. Relationships among peonies cultivars and parental forms were evaluated using a dendrogram based on Nei and Li's (1979) genetic distances. It was generated by the UPGMA (unweight pair group method) cluster analysis method. Calculation of genetic distances and the UPGMA cluster analysis were performed with the TREECON program for Windows V 1.3b (Nei, Li, 1979). Statistical analysis was performed using the Gen Alex 6 program (Peakal, Smouse, 2006). Calculation of the observed number of alleles, Nei's gene diversity $(\mathrm{H})$, Shannon's Information Index (I), Wright's Fixation Index $(\mathrm{F}=1-\mathrm{Ho} / \mathrm{He})$ and generation of a Nei's genetic distance based dendrogram were carried out with the POPGENE V 1.31 software.

\section{RESULTS AND DISCUSSION}

We investigated the phylogenetic relationship among Lithuanian parental forms and cultivars of peony. That kind of research has been done for the first time.

The nine RAPD primers detected a total of 87 fragments ranging from 100-1800 bp in 13 peonies cultivars. Most fragments were detected with the OPA-18 primer. The primer OPB-19, however, generated only one fragment (Table 2).

Parental forms and cultivars are described in Table 1. The most common fragments were detected among the cultivar 'Skeivienès vèlyvasis' and its parental forms 'Germaine Bigot' and 'Eugene Verdier'. Numbers of common fragments of 'Skeivienès velyvasis' with its two parental forms are 20 and 10, respectively. 'Garbé Motinai' has the least common fragment with the parental form 'Germaine Burgos'. They have only one common fragment (Table 3).

The maximum quantity of fragments was amplified using the primers OPA-18, OPB-8 and MP-8. 'Skeivienès vèlyvasis' and its parent 'Germane Bigot' have the most common fragments. They have four common fragments. 'Garbè Motinai' and 'Germaine Burgos' have no common fragments.

With the primer OPA-18 15 fragments were detected. 'Skeivienès vèlyvasis' and its parents remain the lineages with the most common fragments, i. e. 4 fragments between 'Skeivienès vèlyvasis' and 'Germaine Bigot', and 3 between 'Skeivienès vèlyvasis' and 'Eugene Verdier'. 
Table 2. Primers and their sequences used for RAPD analysis

\begin{tabular}{ccccc}
\hline Primers & Primers sequences & Length of fragments, bp & Number of fragments \\
\hline OPB-7 & 5'-AGG TGA CCG T-3' & $390-1350$ & 10 \\
\hline OPB-8 & 5'-GGT GAC GCA G-3' & $480-1800$ & 13 \\
\hline OPB-17 & 5'-GTC CAC AGG G-3' & $340-1600$ & 11 \\
\hline OPB-19 & 5'-AGG GAA CGA G-3' & 400 & 1 \\
\hline OPA-7 & 5'-ACC CCC GAA G-3' & $620-1480$ & 6 \\
\hline OPA-8 & 5'-GTC ATG CCT GGA-3' & $450-1100$ & 9 \\
\hline OPA-18 & 5'-GTA AAA CGA CGG CCA TG-3' & $350-1500$ & 15 \\
\hline MP-5 & 5'-GAA ACG GGT G-3' & $350-1700$ & 8 \\
\hline MP-8 & 5'-GTG ACG TAG G-3' & $100-1400$ & 13 \\
\hline Total: & & $100-1800$ & 86 \\
\hline
\end{tabular}

'Garbė Motinai' and 'Germaine Burgos', 'Freda' and 'Darius-Girenas' and their parental forms have no common fragments.

With the primer OPB-8 13 fragments were identified (Fig. 1). It is one of the best-performing primers. The most common fragments come from 'Skeivienès vèlyvasis' and two of its parents 'Germaine Bigot' (4 common fragments) and 'Eugene Verdier' (3 fragments). 'Garbè Motinai' and 'Germaine Burgos', 'Darius-Girenas' and 'Germaine Burgos', 'Prof. K. Grybauskas', 'Freda' and their parental forms had no common fragments detected by OPB- 8 .

There are 13 fragments identified with the primer MP-8. The most common fragments come from 'Skeivienès vèlyvasis' and its par- ent 'Germaine Bigot' (5 common fragments) (Fig. 2). Common fragments come from 'Garbè Motinai' and 'Germaine Burgos'. Lithuanian cultivars and their parental forms have no common fragments with this primer.

There are no common fragments with the primer OPA-7. With primers OPA- 8 one common fragment was detected from the species 'Skeivienès vèlyvasis' and 'Germaine Bigot'. With the MP-5 primer common fragments were detected from 'Freda' and two of its parents 'Auguste Dessert' ( 1 common fragment) and 'Perette' (2 common fragments), 'Skeivienès vèlyvasis' and one of its parents 'Germaine Bigot'. Other cultivars had no common fragments detected with their parental

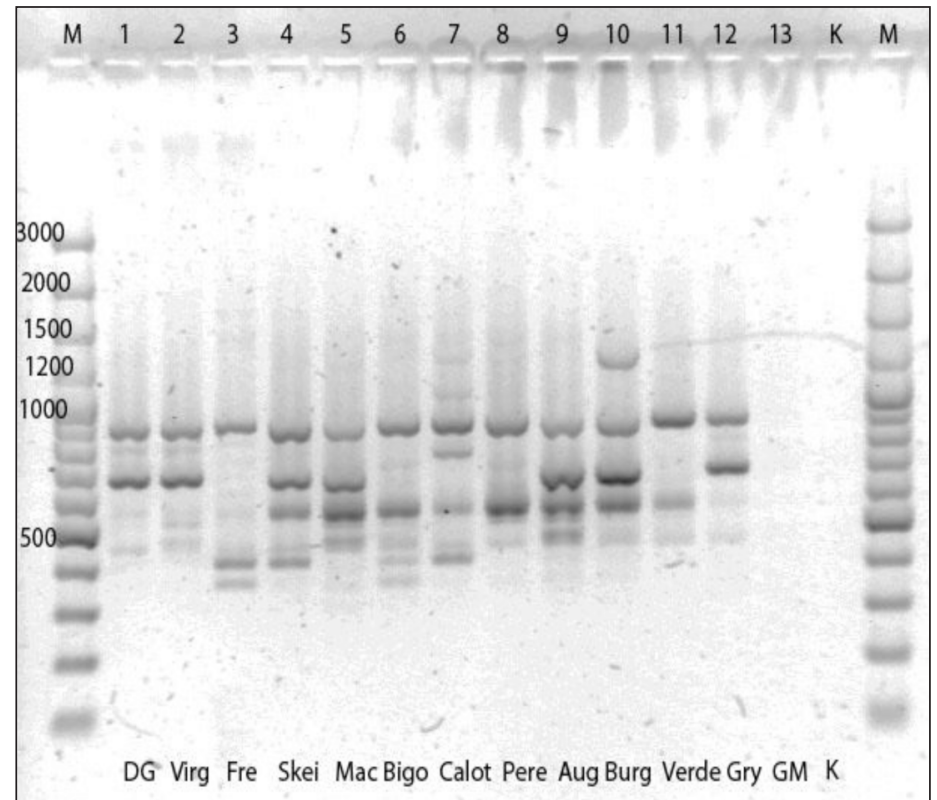

Fig. 1. PCR spectrum of the OPB8 primer. Cultivars: track $1-{ }^{\prime} \mathrm{Da}-$ rius-Girènas'; track 2 - 'Virgilijus'; track 3 - 'Freda'; track 4 - 'Skeivienès vèlyvasis'; track 5 - 'General Mac Mahon'; track 6 - 'Germane Bigot'; track 7 - 'Madame Calot'; track 8 - 'Perette'; track 9 - 'Auguste Dessert'; track 10 'Germaine Burgos'; track 11 - 'Eugene Verdier'; track 12 - 'Prof. K. Grybauskas'; track 13 - 'Garbė Motinai' 


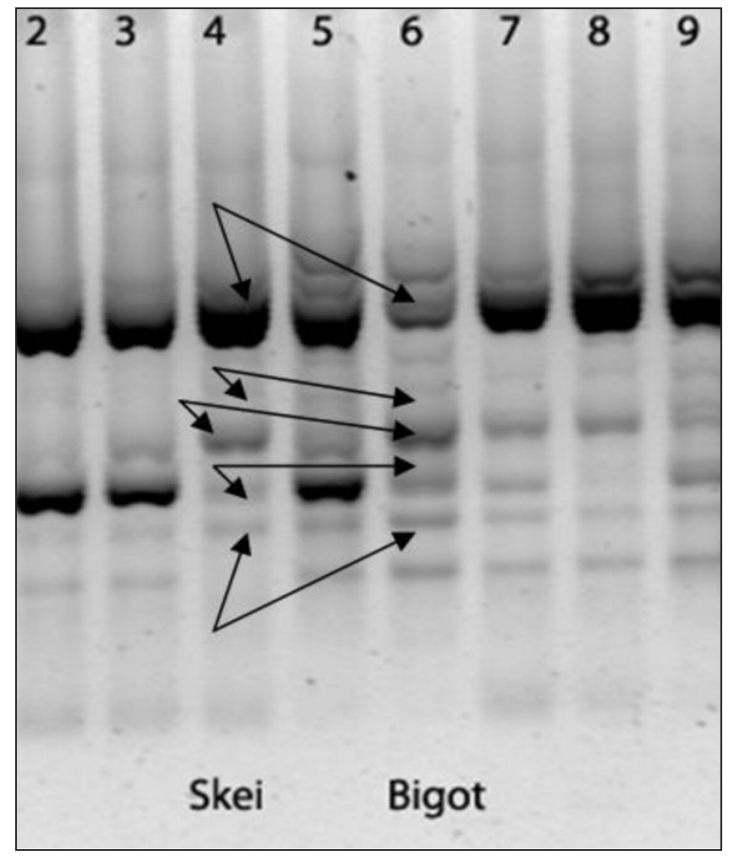

Fig. 2. MP-8 primer part of the spectrum. Common fragments of 'Skeivienès vèlyvasis' (track 4) and its parental form 'Germane Bigot' (track 6)

forms by this primer. There were no common fragments detected between Lithuanian peony cultivars and parental forms had no common fragments detected by the OPB-17. The dendrogram analysis (Fig. 3) showed that the most distant peony cultivars were 'Skeivienès vèlyvasis' and 'Garbè Motinai'. The genetically closest cultivars are 'General Mac Mahon' and 'Germaine Burgos'.
According to the number of common fragments among parental forms and cultivars (Table 3), the dendrogram data showed that the most common parental form was 'Fre$\mathrm{da}^{\prime}$, and the most distant ones were 'DariusGirènas' and 'Skeivienès vèlyvasis'. There were no researches on 'Pierre Reignoux' and the second parental form of 'Virgilijus' and 'Garbe Motinai'.

The NJ tree, however, can give us instructive information. Increasing the knowledge of the molecular diversity of a crop is essential for extending its genetic base, identifying cultivars, and selecting parental varieties for breeding programs. In the sense, tree peony cultivars are poorly characterized. Although many classification methods including many molecular marker systems have been applied to these species, the cultivars are still classified mainly based on traditional phenotypic characteristics such as flower color, flower form, and geographic distribution (WANG and STRECH, 2001).

A UPGMA tree is constructed using the informative fragments as an agent of genetic distance for these peony cultivars (Fig. 3). All branches are statistically supported with the bootstrap value above $25 \%$. Peonies are divided into two clusters according to this dendrogram. The cultivar 'Garbe Motinai' stands separately from these clusters. The parental form 'Germaine Burgos' of this cultivar is in

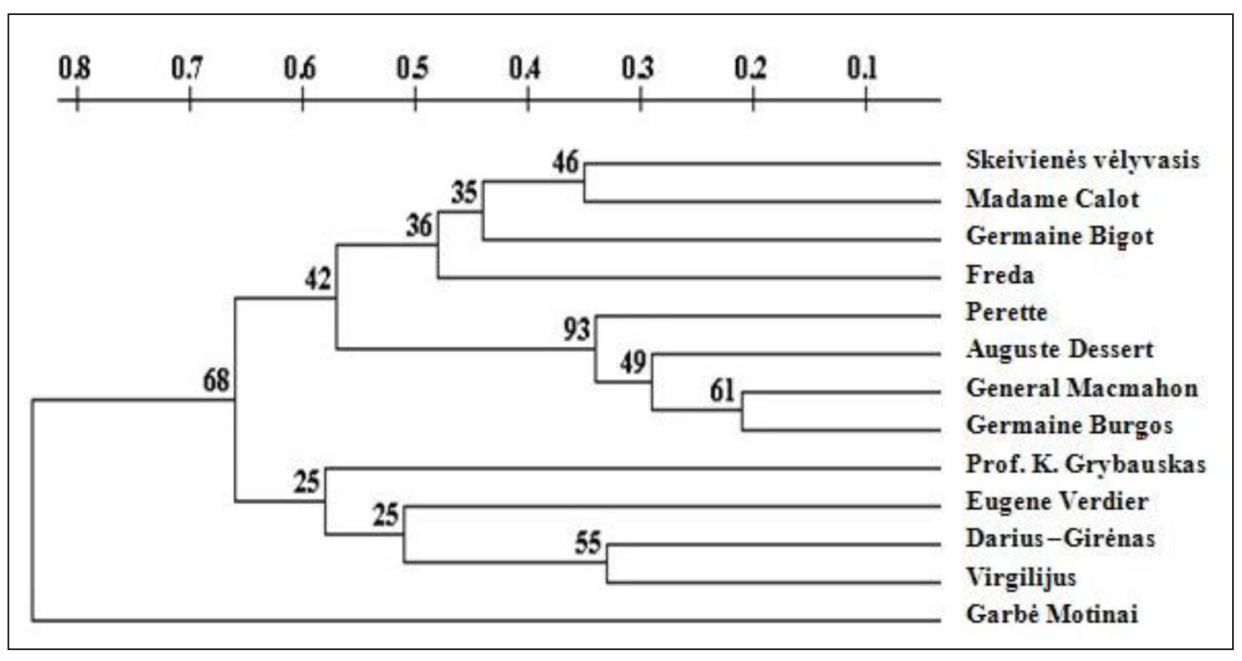

Fig. 3. Dendrogram of the investigated peony cultivars 
Table 3. Comparison of common fragments of the Lithuanian peony cultivars and their parental forms identified using RAPD primers

\begin{tabular}{ccc}
\hline Cultivar & Parental form & Common fragment number \\
\hline 'Virgilijus' & 'Auguste Dessert' & 8 \\
\hline 'Garbe Motinai' & 'Germaine Burgos' & 1 \\
\hline 'Prof. K. Grybauskas' & 'General Mac Mahon' & 7 \\
\hline 'Prof. K. Grybauskas' & 'Perette' & 5 \\
\hline 'Freda' & 'Auguste Dessert' & 7 \\
\hline 'Freda' & 'Perette' & 7 \\
\hline 'Darius-Girènas' & 'Germaine Burgos' & 5 \\
\hline 'Darius-Girènas' & 'Madame Calot' & 20 \\
\hline 'Skeivienės vellyvasis' & 'Germaine Bigot' & 10 \\
\hline 'Skeivienės vèlyvasis' & 'Eugene Verdier' &
\end{tabular}

different cluster of the dendrogram. The cultivars 'Virgilijus', 'Prof. K. Grybauskas' and 'Darius-Girènas' are located in different clusters than their parental forms. One parental form of the cultivar 'Skeivienès velyvasis' is in different cluster 'Germane Bigot' and other parental form of 'Eugene Verdier' is in next cluster. 'Freda' and its parental forms are in the same cluster. According to peony distribution in the dendrogram we can conclude that Lithuanian peony cultivars and their parental forms in clusters are located independently of their genetic relationships. Parental forms can be in the first, second or both first and second clusters, regardless of which cluster cultivar belongs to.

In our research, the Lithuanian hybrid 'Garbè Motinai' occupied a separate branch in the dendrogram. That is why it should attract the interest of peony breeders. Other Lithuanian researches separated Lithuanian cultivars such as 'Garbe Motinai', 'Virgilijus', 'Profesorius K. Grybauskas' and hybrids 'Maironis' and 'Darius Girènas' genetically closer to French cultivars, but highly genetically distant from both investigated genotypes of wild Paeonia lactiflora species (Mažeikienè et al., 2007). In our research, genetic similarity of Lithuanian clones to other countries has not been tested, but some of cultivars that are in the field of interest of other Lithuanian researches are separated in one cluster. This could be because of their origin. Lithuanian peony cultivars and their parental forms in clusters are located independently of their genetic relationships.

Received 11 September 2014

Accepted 1 December 2014

\section{References}

1. Areškevičienė R. Estimation of genetic diversity and identity in plus tree clones of Norway spruce (Picea abies (L.) Karst.) using RAPD method [dissertation]. Akademija; 2009.

2. Lee B, Shin YW, Bae EA, Han SJ, Kim JS, Kang SS, Kim DH. Antiallergic effect of the root of Paeonia lactiflora and its constituents paeoniflorin and paeonol. Arch Pharm Res. 2008; 31(4): 445-50.

3. Cheng Y, Kim CH, Shin D, Kim SM, Koo HM, Park YJ. Developments of simple sequence repeat (SSR) markers to study diversity in the herbaceous peony (Paeonia lactiflora). J Med Plant Res. 2011; 5(31): 6744-51.

4. Chen XM, Zheng GS, Zhang SW. RAPD analysis of tree peony cultivars. Acta Hort Sinica. 2001; 28: 370-2.

5. Dapkūnienė S, Varkulevičienė J, Stankevičienè A, Motiejūnaitè O. Survey of peonies cultivars created in Kaunas Botanical Garden. Sodininkyste ir daržininkystė. 2007; 26(3): $217-25$. 
6. Halevy HA. Evaluation of methods for flowering advancement of herbaceous peonies. HortScience. 2002; 37(6): 885-9.

7. Liu YG, Teng YY, Pan C, Han YC, Zhou MQ, $\mathrm{Hu}$ ZL. Cluster analysis of Nelumbo based on SRAP markers. Amino Acids Biotic Res. 2006; 28: 29-32.

8. Mažeikienè I, Stanys V, Stanienė G. Analysis of DNA polymorphism of herbaceous peony species and cultivars. Sodininkyste ir daržininkystè. 2007; 26(3): 267-73.

9. Mažeikienė I, Stanys V, Morkūnaitè-Haimi Š, Stanienè G. Morphologic and genetic polymorphism of herbaceous peony. Sodininkyste ir daržininkystè. 2008; 27(4): 261-74.

10. Mažeikienė I, Stanienė G, Stanys V. Paeonia lactiflora translation elongation factor - 1 alfa (EF-1a). Homology and expression in micro plants. Sodininkystè ir daržininkystè. 2010; 29(3): 83-93.

11. Murray MG, Thompson WF. Rapid isolation of high molecular weight plant DNA. Nucleic Acids Res. 1980; 8: 4321-5.

12. Nei M, Li WH. Mathematical model for studying genetic variation in terms of restriction endonucleases. Proc Natl Acad Sci USA. 1979; 76: 5269-73.

13. Peakall R, Smouse PE. GENALEX 6: genetic analysis in Excel. Population genetic software for teaching and research. Mol Ecol Notes. 2006; 6: 288-95.

14. Skeivienė O. Outlook on peony varieties. Mūsų sodai. 1964; 11(11): 28-9.

15. Su X, Zhang H, Dong LN, Zhang JQ, Zhu XT, Sun K. RAPD classification and identification of Paeonia rockii varieties planted in Gansu Province. Acta Bot Boreal-Occident Sin. 2006; 26: 696-701.

16. Suo ZL, Zhou SL, Zhang HJ. DNA molecular evidences of the inter-specific hybrids between Paeonia ostii and P. suffruticosa based on ISSR markers. Forest Res. 2004; 17: 700-5.

17. Suo ZL, Zhang HJ, Zhang ZM, Chen FF, Chen FH. DNA molecular evidences of the inter-specific hybrids between Paeonia rockii and P. suffruticosa based on ISSR markers. Acta Bot Yunnan. 2005; 27: 42-8.

18. Varkulevičienè J, Stankevičienė A. The use of peonies of Lithuanian cultivars in city green plantations. In: Urban Green Places Formative Strategy 2005: Proceedings of the International Scientific-Practical Conference. Klaipeda; 2005. p. 128-32.

19. Varkulevičienè J, Stankevičienè A. Introduction and research of Lithuanian cultivars and hybrids of peonies in Kaunas Botanical Garden. Scripta Horti Botanici Universitatis Vytauti Magni. 2006; 11: 36-44.

20. Varkulevičienè J, Mikaliūnaitè R, Malciūtè A. Cultivation of Lithuanian cultivars and hybrids of peonies in Kaunas Botanical Garden. In: Rural Development 2013: Proceedings of the Sixth International Scientific Conference, Volume 6, Book 3. Akademija: Aleksandras Stulginskis University; 2013. p. 262-7.

21. Wang SY, Strech AW. Antioxidant capacity in cranberry is influenced by cultivar and storage temperature. J Agric Food Food Chem. 2001; 49(2): 969-74. 
Judita Varkulevičienė, Judita Žukauskienė

BIJŪNŲ VEISLIŲ IR JŲ TĖVINIŲ FORMŲ ANALIZĖ NAUDOJANT RAPD ŽYMENIS

\section{Santrauka}

Kuriant naujas augalų veisles labai svarbu pasirinkti genetiškai ir morfologiškai besiskiriančius augalus. Genetiniai skirtumai morfologiškai panašių rūšių negali būti vertinami tik pagal išorines savybes. Vytauto Didžiojo universiteto (toliau - VDU) Kauno botanikos sodo bijūnų kolekcijoje bijūnų veislès turi labai skirtingas morfologines savybes: skiriasi pagal aukští, žiedų tipą, formas ir spalvas, aromatines funkcijas, jų stiprumą, o taip pat stiebų skaičių, lapų tankị ir spalvą, žydejjimo laiką ir trukmę. VDU Kauno botanikos sodo bijūnų kolekcijoje pavasari buvo atlikti DNR tyrimai. Tirta puikiojo bijūno (Paeonia lactiflora) 6 lietuviškos veislès ir
7 tèvinès formos. Parinktos naujai sukurtos lietuviškos bijūnų veislès, kurios skyrèsi genetiškai, morfologiškai ir fiziologiškai. Genetiniai skirtumai tarp 13 skirtingų bijūnų veislių buvo palyginti naudojant atsitiktinai pagausintos polimorfinès DNR (APPD, angl. - RAPD) metodą. Daugiausiai polimorfinių DNR fragmentų pagausinta su keturiais pasirinktais pradmenimis MP-8, OPB-7, OPA-18 ir OPB-8. Bendras DNR fragmentų skaičius svyravo nuo 1 iki 15, o jų dydis - 100-1 800 bp. Genetiškai labiausiai viena nuo kitos nutolusios bijūnų veislès - 'Skeivienès vèlyvasis' ir 'Garbè Motinai'; genetiškai panašiausios veislès - 'General MacMahon' ir 'Germaine Burgos'; genetiškai panašiausia tèvinèms formoms veislè - 'Freda', o labiausiai nutolusios - 'Darius-Girènas' ir 'Skeivienès vèlyvasis'.

Raktažodžiai: puikusis bijūnas, veislès, lietuviškos, APPD 